\title{
Analysing the satisfaction of halal restaurant guests through online ratings on TripAdvisor
}

\section{Istraživanje zadovoljstva gostiju halal restorana kroz onlajn ocene na TripAdvisor-u}

Jelena Tepavčevića*, Milan Bradić, Slobodan Luković

${ }^{a}$ University of Novi Sad, Faculty of Science, Department of Geography, Tourism and Hotel Management, Serbia

\begin{abstract}
Providing halal products is one of the key factors in the lives of members of the Islamic faith. The physical and economic availability of halal food has an important place in the decision-making process about the movements of Muslim tourists. Currently, the Halal market is rapidly expanding, contributing to an increase in the number of the Muslim population and their travels. The main goal is to analyse the satisfaction of halal restaurant guests expressed through online numerical ratings. Authors used automated techniques for collecting guests' ratings. Restaurants that were analysed were chosen by selecting the criteria "halal" on TripAdvisor. Information about the origin of reviewers and gender are also collected. The paper also tries to answer the question whether the origin of guests and type of halal restaurants have an influence on their satisfaction with services in selected facilities. The results indicated the presence of significant differences in guest's satisfaction among different types of restaurants. One of the possible limitations of this research is an insufficient number of evaluating criteria for expressing a satisfaction which are available on TripAdvisor for analysis that is more precise.
\end{abstract}

Keywords: guest satisfaction, halal, tourism, hospitality, ratings, TripAdvisor.

Sažetak: Postojanje halal proizvoda je jedan od ključnih faktora u životu pripadnika islamske vere. Fizička i ekonomska dostupnost halal proizvoda igraju važnu ulogu u procesu donošenja odluka o turističkim kretanjima Muslimana. Svakako da se tržište halala brzo širi, doprinoseći porastu muslimanske populacije i njihovim putovanjima. ali Glavni cilj rada jeanaliza zadovoljstva gostiju halal restorana koje je iskazano kroz onlajn numeričko ocenjivanje. Autori su koristili automatizovane tehnike prikupljanja podataka. Analizirani restorani birani su selektovanjem kriterijuma "halal" na TripAdvisor-u. Prikupljeni su podaci o poreklu i polu

${ }^{*}$ Corresponding author

E-mail address: jelenat91@gmail.com

This is an open access paper distributed under the license (c) (1) (9) 
ocenjivača. Rad takođe pokušava da odgovori na pitanje da li poreklo gostiju i tip halal restorana imaju uticaj na njihovo zadovoljstvo uslugama u odabranim restoranima. Rezultati pokazuju prisustvo značajne razlike u zadovoljstvu gostiju u odnosu na tip restorana. Jedno od mogućih ograničenja ovog istraživanja je nedovoljan broj kriterijuma vezanih za ocenu zadovoljstva na TripAdvisor-u kako bi analiza bila što preciznija.

Ključne reči: zadovoljstvo gostiju, halal, turizam, ugostiteljstvo, ocene, TripAdvisor

\section{Introduction}

Halal food is an important factor in the lives of the Muslim population. The ability to be accessed as well as the quality of halal food products are different around the world. Halal food and beverages are in accordance with the rules of Islam. Islam is the second-largest religion, and it is most represented in the countries of North Africa, the Middle East, and South Asia (Çakmak, 2008). For some food to be labelled as "halal", some conditions must be fulfilled. First, halal food must not contain any parts or additives that originate from forbidden animals or ingredients (for example, alcoholic beverages). It is common practice that halal products originate from so-called halal animals, e.g. goats, sheep or cows, as well as seafood. In addition, the slaughter of these animals is strictly prescribed (Regenstein et al., 2003). Another important rule is that halal product must be manufactured, manipulated, and stored using tools, equipment and apparatuses cleansed in accordance with Islamic law (Hall et al., 2003). This rule means that these tools and accessories must not come into contact with forbidden food and ingredients. The halal market can be found wherever Muslims live, but lately, it is obvious that there is a trend of expansion of this market to parts of the world where Muslims travel and move. The increase in demand for halal products in Europe is partly caused by the forced migration of population. This trend is also evident in the Balkans, which represents not only the transit migration area of the Muslim population of the Middle East and the South Asia but also top growing area of touristic movements in Europe (UNWTO, 2018).

\section{Literature review}

\subsection{Concept of halal}

Although halal is a highly potent market of the future, it has not been fully explored. This is supported by the growing number of members of the Muslim community, which is estimated at around 2 billion at the end of the second decade of the $21 \mathrm{st}$ century, with the current estimated value of halal market over 2.5 billion dollars (Halim et al., 2014). Due to its recognisability as an alternative benchmark for safety, hygiene and quality assurance of beverages and food, the concept of "halal" is represented in discussions around the world. Therefore, halal food products are widely accepted by consumers across other parts of the world, as well as by Muslim consumers. Therefore, today consumers are more concerned and take additional care about what they use. Hence, it is very important for consumers to know aspects that influence their confidence level which is related to specific food or diet (Iancu \& Nedelea, 2018). Muslim orientation on the consumption of halal products can be explained by religious beliefs, exposure, certification labels and health reasons. 
However, health reasons are the foremost (Ambali \& Bakar, 2014; Alzeer, Rieder \& Hadeed, 2018).

Many factors influence the implementation of halal system. Authority (Yusuf et al., 2015; Soraji et al., 2016), cost (Sham et al., 2017; Zailani et al., 2017), market competitiveness (Viverita et al., 2017) and supplier management (Saad et al., 2013; Ismail et al., 2016; Krishnan et al., 2017) have been identified as challenging regarding to implementation of Halal system. Besides that, information and knowledge, teamwork, support, policy, procedures, and training are also important determinants of successful implementation of the system (Ahmad et al., 2017). Currently, the harmonisation of halal quality is significantly based on domestic logistics where Muslim consumers prefer direct contact with local producers, i.e. with individuals whose reputation is known and with similar moral and religious beliefs. Today, Halal food concept is above the understanding of purely religious values. Halal represents hygiene, cleanliness and quality of consumed food (Mathew, Abdullah \& Ismail, 2014).

\subsection{Halal tourism}

Halal tourism is one of the recent phenomena of the emerging halal industry. Since halal is essential for improving tourism industry, many Muslim and non-Muslim countries are trying to attract a part of the Muslim tourist market by providing tourism products, facilities and infrastructure that will meet their needs. While affirming a new phenomenon, there is a noticeable lack of theoretical publications and research in this field (Samori et al., 2016). Halal tourism can be defined as "any tourism object or action which is permissible according to Islamic teachings to use or engage by Muslims in tourism industry" (Battour \& Ismail, 2015, p.2). Therefore, the success in the developing and marketing of the halal tourist destination must be guided by the acceptance of Islamic learning and principles in all aspects of tourism activity (Battour \& Ismail, 2015).

There are many motives for Muslims to travel. Some of them are directly connected with Islamic Shari'ah (i.e. Hajj and Umrah), education, medical treatments and other pure tourist reasons (El-Gohary, 2016). For the production of halal food, companies have great potential to attract non-Muslim consumers as the target market because of the growing health concerns. Many countries believe that they can become an attractive destination for Muslim tourists. However, the study conducted by WanHassan \& Awang (2009) showed that Muslim tourists often have difficulties in finding halal food, and there are many of them who must prepare their own food while travelling. By exploring national tourist organization of China, South Korea, Japan, and Thailand through their official web sites Yousaf \& Xiucheng (2018) showed that these countries are trying to use the potentials of their countries as favourite halal tourist destination by introducing and promoting halal gastronomy, halal culture of food, halal restaurant and halal service in general. However, this was not the case with China, which is facing ethnic and religious problems in the strategy of development of gastronomy tourism. 


\subsection{Halal in restaurant industry}

Changing the trend and today's way of life, such as more women in managerial positions, extended working hours, increased revenues and a more complicated daily schedule have led to more and more consumers eating out from their homes. Consumer experience has a significant influence on satisfaction and behavioural intention. Tama \& Voon (2014) identified 6 components of the emotional experiences of consumers in Halal restaurants and those are: spiritual assurance, pleasure, arousal, dominance, joy, and acceptance. Service quality is a critical factor for the success of fast-food restaurants. Managers of fast-food restaurants should continuously measure and improve the quality of their restaurant's services. Furthermore, the way consumers perceive service quality depends on the type of service and the context in which the service is provided. In this regard, Sumaedi \& Yarmen (2015) proposed model for measuring fast food restaurant service quality. This model was consisted of eight dimensions deployed into three groups. Each group consisted of general and Islamic dimension of quality. It was confirmed that the subjective norms, perceived behaviour of people from the environment as well as the inner ambience itself have a significant influence on intention of visiting halal restaurants (Al-Nahdi al., 2009).

\subsection{Restaurant customer satisfaction}

In their study Kivela et. al (2000) found a positive correlation between satisfaction of expectations and willingness to return. Weiss, Feinstein \& Dalbor (2005) based their study on examining four theme restaurants attributes and their impact on intention to visit the restaurant again. Four restaurants' attributes (food quality, service quality, atmosphere and novelty) were examined, and results suggest that novelty affects guest satisfaction the least. They also found that food quality and atmosphere are significant predictors of return intent. Andaleeb \& Conway (2006) suggest that dissatisfied customers are responsible for spreading negative word-of-mouth. They also propound those restaurateurs need to focus efforts on service quality, price and food quality for the purpose of satisfaction of guests. Namkung et. al (2008) identified key quality attributes which make a difference between satisfied and non-satisfied customers. Their study suggests that attributes such as interior design, pleasing background music, responsive service, food presentation, seating arrangement, reliable service and competent employees contribute to high satisfaction. Abdelhamied (2011) tried to identify customers' perceptions of the floating restaurants and to examine the impact of different attributes in restaurants on customer satisfaction. Results showed that healthy dishes, parking spaces, local dishes and restroom cleanliness have an influence on customer intention to revisit. Therefore, Jani \& Han (2011) investigated factors that increase full-service restaurant customers' intentions. Their results suggest that satisfaction of customers is direct antecedent to trust, but it is indirect to commitment. They also pointed out that service encounter performance has a direct impact on customer satisfaction. Khan et al. (2013) found that brand and service quality are key factors that affect satisfaction in fast-food industry. In their study, Nguyen et al. (2018) identified that physical attributes of service quality (tangible) are key to customer satisfaction. Rhee et al. (2016) found the food is very important criteria in selecting restaurants, followed by value, atmosphere, and service. 


\section{Methodology}

One of the main goals of this research was to explore the satisfaction of halal restaurant guests that is expressed in a form of numerical rating on the TripAdvisor portal. TripAdvisor (www.tripadvisor.com) was used because it is a popular travel review site with a complete and understandable database of hotels and restaurants with a numerous number of reviews written by people from all over the world. Some authors used TripAdvisor as a basis for their research (Chaves et al., 2012; Crotts et al., 2009; Li et. al., 2015). The data were collected using automated techniques (web crawler) for data collection and analysis. Although textual reviews were available, only numerical ratings were collected. Restaurants that were included in research were chosen by selecting the criteria "halal" on TripAdvisor. Data were collected in January 2020. In total, 29 restaurants from 6 capital cities of the former Yugoslav countries (Ljubljana, Zagreb, Sarajevo, Belgrade, Podgorica and Skopje) were included in the research. These restaurants were grouped based on type: classic fast-food, pie shops, grill shops ${ }^{1}$ and full-service restaurants. In addition to the ratings provided by guests, information about the place or country they come from, and gender of reviewers were also collected. Reviewers in TripAdvisor often choose to conceal information about their gender, age, and country they come from, so only ratings from reviewers with all necessary information were collected. Place (country) they come from was the basis for grouping reviewers into regions and as a result six regions were obtained: Europe, the Middle and the Far East, North America, and Canada, Central and Latin America, Africa and Oceania. Also, based on country they come from, guests were divided into domestic and foreign for each city separately. After a database was set, reviews with some missing values were discarded, and the final set of 4.178 data were used for further analysis.

Based on this, we proposed the following hypotheses:

$H_{1}$ : There are significant differences in guests' satisfaction according to their origin.

$\mathrm{H}_{2}$ : There are significant differences in guests' satisfaction according to region they come from.

$H_{3}$ : There are significant differences in guests' satisfaction according to type of restaurant.

\section{Results and discussion}

By analysing information about offering halal food in restaurants present on TripAdvisor, it can be noticed that the largest number of restaurants that apply halal standards in their business are located in Sarajevo in comparison to other cities (Table 1). The sample included 7 fast-food restaurants, 2 pie shops, 5 grill shops and 15 fullservice restaurants. The highest number of ratings were collected from guests who visited grill shops $(42,2 \%)$ and the least from fast-food restaurants $(8,5 \%)$. By a crosssectional analysis of preferences for a certain type according to the gender of guests, it was found that male reviewers $(61.2 \%)$ were more frequent in all types of restaurants than female reviewers (38.8\%). Referring to the number of restaurants according to

${ }^{1}$ Ćevabdžinica 
type, full-service restaurants are the most numerous $(15,51.72 \%)$, but there are the least pie shops $(2,6.89 \%)$. Observing the number of ratings obtained on the portal, it can be drawn out that grill shops have the greatest number of ratings $(1759,42.10 \%)$, followed by full-service restaurants $(1164,27.86 \%)$. Fast food restaurants have the least number of ratings $(356,8.52 \%)$.

Table 1. Sample description by cities

\begin{tabular}{ccc}
\hline City & Total reviews & Number of restaurants \\
\hline Belgrade & 280 & 5 \\
Skopje & 548 & 2 \\
Sarajevo & 2.347 & 12 \\
Zagreb & 353 & 6 \\
Ljubljana & 627 & 3 \\
Podgorica & 23 & 1 \\
\hline
\end{tabular}

Source: Authors

Distribution of guests according to the region is shown in Table 2. It is obvious that most guests are from Europe, but there is a significant number of guests from Middle and Far East, who are the most common consumers of halal food (ITC, 2015). The least number of guests came from African continent. The largest number of guests who visited and rated halal restaurants came from Sarajevo, which is not surprising because Muslims are the majority of the population in Sarajevo (ASBH, 2018) and local restaurant owners are trying to meet the needs of Muslim residents.

Table 2. Distribution of guests according to region

\begin{tabular}{ccccccc}
\hline \multirow{2}{*}{ Region } & \multicolumn{7}{c}{ Frequency of guests } \\
\cline { 2 - 7 } & Belgrade & Skopje & Sarajevo & Zagreb & Ljubljana & Podgorica \\
\hline Europe & 218 & 255 & 1.529 & 274 & 519 & 17 \\
\hline $\begin{array}{c}\text { Middle and } \\
\text { Far East }\end{array}$ & 34 & 248 & 566 & 37 & 46 & 5 \\
\hline $\begin{array}{c}\text { North } \\
\text { America }\end{array}$ & 16 & 31 & 141 & 26 & 10 & 1 \\
\hline $\begin{array}{c}\text { Central and } \\
\text { Latin } \\
\text { America }\end{array}$ & 1 & 1 & 51 & 7 & 38 & 0 \\
\hline Africa & 8 & 2 & 11 & 2 & 4 & 0 \\
\hline Oceania & 3 & 4 & 49 & 7 & 10 & 0 \\
\hline
\end{tabular}

Source: Authors

T-test of independent samples (Table 3) was applied to determine the existence of significant differences in restaurant ratings according to the origin of guests (domestic/foreign guests). Significant differences were determined between ratings given by domestic and foreign guests in Skopje and Zagreb in the sense that foreign guests give statistically significant lower ratings than domestic guests do. These results confirmed $\mathrm{H}_{1}$. 
Table 3. T-test of independent samples according to origin of guests

\begin{tabular}{|c|c|c|c|c|}
\hline City & $\mathrm{N}$ & Mean & $\mathrm{T}-$ value & $p$ \\
\hline Belgrade & $\begin{array}{c}\text { Domestic }(\mathrm{N}=120) \\
\text { Foreign }(\mathrm{N}=160)\end{array}$ & $\begin{array}{l}4.150 \\
3.838 \\
\end{array}$ & 1.999 & .051 \\
\hline Skopje & $\begin{array}{l}\text { Domestic }(\mathrm{N}=69) \\
\text { Foreign }(\mathrm{N}=479)\end{array}$ & $\begin{array}{l}4.159 \\
3.754 \\
\end{array}$ & 2.657 & $.009^{*}$ \\
\hline Sarajevo & $\begin{array}{l}\text { Domestic }(\mathrm{N}=276) \\
\text { Foreign }(\mathrm{N}=2.071)\end{array}$ & $\begin{array}{l}4.340 \\
4.436 \\
\end{array}$ & -1.404 & .161 \\
\hline Zagreb & $\begin{array}{c}\text { Domestic }(\mathrm{N}=147) \\
\text { Foreign }(\mathrm{N}=206)\end{array}$ & $\begin{array}{l}4.354 \\
4.117 \\
\end{array}$ & 2.129 & $.034^{*}$ \\
\hline Ljubljana & $\begin{array}{c}\text { Domestic }(\mathrm{N}=156) \\
\text { Foreign }(\mathrm{N}=471)\end{array}$ & $\begin{array}{l}4.372 \\
4.236 \\
\end{array}$ & 1.346 & .179 \\
\hline Podgorica & $\begin{array}{l}\text { Domestic }(\mathrm{N}=6) \\
\text { Foreign }(\mathrm{N}=17)\end{array}$ & $\begin{array}{l}4.833 \\
4.353 \\
\end{array}$ & 1.072 & .296 \\
\hline
\end{tabular}

${ }^{*} p<0.05$

Source: Authors

By using the analysis of variance ANOVA, the authors examined whether there are significant differences between the independent variable (region from which guests come) and dependent variable (guests' ratings). The result of one-way variance has shown that there are significant differences in ratings given by guests from different regions (Table 4). In order to establish differences between the certain groups, the LSD post-hoc test was applied. The results show that guests from the Middle and the Far East are those who give statistically significant lower ratings than guests from Europe. It can be explained by the fact that guests from the Middle and the Far East are more familiar with halal, so their perception of the quality of halal food is more stringent, as well as their satisfaction. These results confirmed $\mathrm{H}_{2}$.

Table 4. Analysis of variance ANOVA according to region

\begin{tabular}{cccccc}
\hline Region & Average Rating & F-value & p & $\begin{array}{c}\text { LSD post- } \\
\text { hoc }\end{array}$ \\
\hline Europe & 4.311 & & & \\
\cline { 1 - 2 } Middle and Far East & 4.199 & & & \\
\cline { 1 - 2 } Central and Latin America & 4.377 & & & \\
\cline { 1 - 2 } North America and Canada & 4.245 & & $.041^{*}$ & $2<1$ \\
\hline Africa & 4.273 & & & \\
\hline Oceania & 4.070 & & & \\
\hline${ }^{*} p<0.05$ & & & &
\end{tabular}

Source: Authors

The authors analysed the variance ANOVA (Table 5) in order to examine whether there are significant differences between the independent variable (restaurant type) and dependent variable (guests' ratings). The results have shown that there are significant differences in ratings in the sense that full-service restaurants have significantly lower ratings than fast foods, pie shops and grill shops. Taking into account that mealtime in full-service restaurants is usually longer, there are some differences in forming the final impression about quality which affects satisfaction. For example, in full-service restaurants guests will pay attention to atmosphere and quality of interaction (Marinkovic et al., 2014), while in other types of restaurants 
these dimensions are not so important, so there is another way for creating a quality perception and affecting guest's satisfaction. These results confirm $\mathrm{H}_{3}-$ it is proved that there are significant differences in guests' satisfaction among different types of restaurants.

Table 5. Analysis of variance ANOVA according to the restaurant type

\begin{tabular}{|c|c|c|c|c|}
\hline Restaurant type & Rating & F-value & $\mathrm{p}$ & $\begin{array}{c}\text { LSD post- } \\
\text { hoc }\end{array}$ \\
\hline Fast food $(\mathrm{N}=357)$ & 4.447 & \multirow{4}{*}{38.479} & \multirow{4}{*}{$.000^{* *}$} & \multirow{4}{*}{$4<1,2,3$} \\
\hline Pie shop $(\mathrm{N}=899)$ & 4.547 & & & \\
\hline Grill shops $(\mathrm{N}=1759)$ & 4.222 & & & \\
\hline Full-service restaurant $(\mathrm{N}=1163)$ & 4.079 & & & \\
\hline
\end{tabular}

Source: Authors

\section{Conclusion}

As an important factor in the lives of members of Islamic faith around the world, the Halal concept of nutrition has become increasingly important in tourist, that is, hospitality offer. Ensuring accessibility and the required quality of halal products is one of the prerequisites for satisfying the needs of Muslim travellers. Muhammad et al (2007) pointed out the benefits of halal food for everyone in general, not only for Muslims. Recent studies among non-Muslim consumers found that acceptance of halal food is related to nutrition, safety and quality attributes of halal food (Aziz \& Chok, 2013; Haque et al., 2015; Latif et al., 2014; Mathew et al., 2014; Rezai et al., 2012). The results of this study showed that Sarajevo (Bosnia and Herzegovina) is leading in offering halal food compared to other observed cities, which is not surprising because of the religious and cultural environment. Although the number of guests is predominantly those from European countries, there is a noticeable presence of guests from Asia (Middle and Far East), which is in accordance with statistic data about increasing receptive touristic traffic from these parts of the world (UNWTO, 2019).

The aim of this study was to examine the satisfaction of guests of halal restaurants in 6 cities. First, it has been determined that the origin of guests (domestic/foreign) have an impact on satisfaction. Statistically significant differences in satisfaction exists among domestic and foreign guests in Skopje $(\mathrm{p}=.009)$ and Zagreb $(\mathrm{p}=.034)$ were determined, in the sense that domestic guests express higher satisfaction in relation to the foreign ones. The results of this study confirmed results obtained in Živadinović (2020) study, who found that domestic guests in Skopje are more satisfied with restaurant services than foreign guest. Also, it was found that the region they come from is a significant predictor of differences in satisfaction. Statistically significant differences exist between guests from Middle/Far East and Europe. Halal certification is a kind of assurance and creates a sense of trusts among Muslims, but Islamic literature highlights that in the absence of halal logo, Muslims are looking for cues that services or products are safe for consumption (Jamal \& Sharifuddin, 2015). Due to the suspicion that food or services in examined restaurants are haram, it can be assumed that this is the main cause of lower satisfaction among guest from Middle/Far 
East. Besides, it has also been shown that the satisfaction of guests depends on the restaurant type, where full-service restaurants have significantly lower ratings than fast foods, pie shops and grills shops.

Guest satisfaction is a complex category and consists of numerous factors that influence it. However, on TripAdvisor guests may evaluate their experience and satisfaction only through four criteria - food, service, value, and atmosphere. In recent research it was found that cleanliness, service, ambience, health issues and price have an influence on restaurant selection (Choi \& Zhao, 2016). Also, Rahman et al. (2012) found that image of restaurant, accuracy in serving food and speed of service have a significant impact on guest satisfaction. Based on this, the possibility of evaluating more dimensions of satisfaction could be helpful in improving quality of service.

Although there is a number of studies involved in online reviews and ratings of consumers, the lack of this sort of studies in the restaurant industry is evident. This research contributes to the literature in the field of guest satisfaction in the restaurants by confirming that guest satisfaction varies depending on the type of restaurant. Therefore, the factors that affect satisfaction in different types of restaurants should be investigated in more detail, to increase satisfaction and build trust among guests. Restaurateurs should pay attention to crucial elements for operating - quality of food and good service. Practical implication implies the importance of following consumer reviews on portals like TripAdvisor in order to continuously improve the service quality. Positive eWOM is very important in order to increase purchase intentions and create a positive image about the company. Considering that satisfied guests will share positive opinions about their experience, restaurant managers can use their reviews and ratings for creating a powerful marketing tool for achieving loyalty and creating trust among guests. In addition, negative reviews and ratings are as important as a positive one. By analysing a negative review, it is possible to establish which segments need to be improved in order to provide better services and enhance satisfaction.

The recommendation for future research is to consider both numerical ratings and textual reviews to see the full impression of guests and factors that have contributed to their satisfaction. In the analysis of textual reviews, more detailed attention could be devoted to possible differences from the geographical and linguistic (cultural) aspects. In any case, the different perceptions, and expectations of different segments of demand must be considered.

\section{Acknowledgement}

This research is part of the project 'Transformation of geospace in Serbia - past, current problems and solution proposals', approved by the Ministry of Education, Science and Technological Development of Republic of Serbia (registration number: 176020 OI) 


\section{References}

Abdelhamied, H. H. (2011). Customers' perceptions of floating restaurants in Egypt. Anatolia-An International Journal of Tourism and Hospitality Research, 22(1), 1-15. https://doi.org/10.1080/13032917.2011.556212

Ahmad, A. N., Rahman, R. A., Othman, M., \& Abidin, U. F. U. Z. (2017). Critical success factors affecting the implementation of halal food management systems: Perspective of halal executives, consultants and auditors. Food Control, 74, 70-78. https://doi.org/10.1016/j.foodcont.2016.11.031

Al-Nahdi, Md.T.S.M., Ismail, I., Haron, H., \& Islam, Md.A. (2009). Intention to Patronage Halal Restaurants Among Malaysian Muslims - An Issue of Halal Perception.The Gsmi (First) Global Business Summit Conference (78-86). Michigan, USA, Refereed Proceeding.

Alzeer, J., Rieder U., \& Hadeed, A.K. (2018). Rational and practical aspects of Halal and Tayyib in the context of food safety. Trends in Food Science \& Technology, 71, 264-267. https://doi.org/10.5167/uzh-169451

Ambali, A. R., \& Bakar, A. N. (2014). People's Awareness on Halal Foods and Products: Potential Issues for Policy-Makers. Procedia - Social and Behavioural Sciences, 121, 3-25. https://doi.org/10.1016/j.sbspro.2014.01.1104

Andaleeb, S.S., \& Conway, C. (2006). Customer satisfaction in the restaurant industry: An examination of the transaction-specific model. Journal of Services Marketing, 20(1), 3-11. https://doi.org/10.1108/08876040610646536

ASBH - Agency for Statistics of Bosnia and Herzegovina, Demography and Social Statistics. Sarajevo, BIH. (2018) Retrieved from: https://www.bhas.ba/saopstenja/2018/DEM_01_2018_Q3_0_BS.pdf

Aziz, Y.A. \& Chok, N.V. (2013). The role of halal awareness, halal certification, and marketing components in determining halal purchase intention among nonMuslims in Malaysia: a structural equation modeling approach. Journal of International Food and Agribusiness Marketing, $25(1)$, 1-23. https://doi.org/10.1080/08974438.2013.723997

Battour, M., \& Ismail, M.N. (2015). Halal tourism: Concepts, practices, challenges and future. Tourism Management Perspectives, 19, 150-154. https://doi.org/10.1080/08974438.2013.723997

Çakmak, C. (Ed.). (2017). Islam: A Worldwide Encyclopedia [4 volumes]. ABCCLIO.

Chaves, M. S., Gomes R., \& Pedron, C. (2012). Analysing Reviews in the Web 2.0: Small and Medium Hotels in Portugal. Tourism Management,33(5), 1286-1287. https://doi.org/10.1016/j.tourman.2011.11.007

Choi, J., \& Zhao, J. (2010). Factors influencing restaurant selection in south florida: Is health issue one of the factors influencing consumers' behavior when selecting a restaurant?. Journal of Foodservice Business Research, 13(3), 237251. https://doi.org/10.1080/15378020.2010.500254

Crotts, J. C., Mason, P. R., \& Davis, B. (2009). Measuring guest satisfaction and competitive position in the hospitality and tourism industry: An application of stance-shift analysis to travel blog narratives. Journal of Travel Research, 48(2), 139-151. https://doi.org/10.1177\%2F0047287508328795 
El-Gohary, H. (2016). Halal tourism, is it really Halal?. Tourism Management Perspectives, 19, 124-130. https://doi.org/10.1016/j.tmp.2015.12.013

Halim, M. A. A., Mohd, K. W., Salleh, M. M. M., Yalawae, A., Omar, T. S. M. N. S., Ahmad, A., Ahmad, A. A., \& Kashim, M. I. A. M. (2014). Consumer Protection of Halal Products in Malaysia: A Literature Highlight. Procedia - Social and Behavioral Sciences, 121, 68-78. https://doi.org/10.1016/j.sbspro.2014.01.1109

Hall, C.M., Sharples, L., Mitchell, R., Macionis, N., \& Cambourne, B. (2003). Food Tourism Around the World. London: Elsevier Ltd.

Haque, A., Sarwar, A., Yasmin, F., Tarofder, A.K. \& Hossain, M.A. (2015). NonMuslim consumers' perception toward purchasing halal food products in Malaysia. Journal of Islamic Marketing, 6(1), 133-147. https://doi.org/10.1108/JIMA-04-2014-0033

Iancu, I.A., \& Nedelea, A.M. (2018). Consumer Confidence from Cluj-Napoca Metropolitan Area, in the Food Labeling System. Amfiteatru Economic, 20(47), 116-133. http://dx.doi.org/10.24818/ea/2018/47/116

Ismail, F. H., Tamby Chik, C., Muhammad, R., \& Mat Yusoff, N. (2016). Food Safety Knowledge and Personal Hygiene Practices amongst Mobile Food Handlers in Shah Alam, Selangor. Procedia - Social and Behavioral Sciences, 222(1), 290298. https://doi.org/10.1016/j.sbspro.2016.05.162

ITC - International Trade Centre, 2015. From niche to mainstream - Halal Goes Global. [pdf] Geneva: The International Trade Centre. Retrieved from: https://www.intracen.org/uploadedFiles/intracenorg/Content/Publications/Hal al_Goes_Global-web(1).pdf

Jamal, A., \& Sharifuddin, J. (2015). Perceived value and perceived usefulness of halal labeling: The role of religion and culture. Journal of Business research, 68(5), 933-941. https://doi.org/10.1016/j.jbusres.2014.09.020

Jani, D., \& Han, H. (2011). Investigating the key factors affecting behavioral intentions: Evidence from a full-service restaurant setting. International Journal of Contemporary Hospitality Management, 23(7), 1000-1018. https://doi.org/10.1108/09596111111167579

Khan, S., Hussain, S. M., \& Yaqoob, F. (2013). Determinants of customer satisfaction in fast food industry a study of fast-food restaurants Peshawar Pakistan. Studia commercialia Bratislavensia, 6(21), 56-65. http://dx.doi.org/10.2478\%2Fstcb2013-0002

Kivela, J., Inbakaran, R., \& Reece, J. (2000). Consumer research in the restaurant environment. Part 3: analysis, findings and conclusions. International Journal of Contemporary Hospitality Management, 12(1), 13-30. https://doi.org/10.1108/09596110010304984

Krishnan, S., Omar, C. M. C., Zahran, I., Syazwan, N., \& Alyaa, S. (2017). The awareness of Gen Z's toward halal food industry. Management, 7(1), 44-47. https://dx.doi.org/10.5923/j.mm.20170701.06

Latif, I. A., Mohamed, Z., Sharifuddin, J., Abdullah, A. M., \& Ismail, M. M. (2014). A comparative analysis of global halal certification requirements. Journal of Food Products Marketing, 20(sup1), 85-101. https://doi.org/10.1080/10454446.2014.921869 
Li, G., Law, R., Vu, H. Q., Rong, J., \& Zhao, X. R. (2-015). Identifying emerging hotel preferences using emerging pattern mining technique. Tourism Management, 46, 311-321. https://doi.org/10.1016/j.tourman.2014.06.015

Marinkovic, V., Senic, V., Ivkov, D., Dimitrovski, D., \& Bjelic, M. (2014). The antecedents of satisfaction and revisit intentions for full-service restaurants. Marketing Intelligence \& Planning, 32(3), 311-327. https://doi.org/10.1108/MIP-01-2013-0017

Mathew, V.N., Abdullah, A.M.R.A., \& Ismail, S.N.M. (2014). Acceptance on Halal Food among Non-Muslim Consumers. Procedia - Social and Behavioral Sciences, 121, 262-271. https://doi.org/10.1016/j.sbspro.2014.01.1127

Muhammad, R. (2007). Re-branding halal. The Halal Journal, 32(May/June), 32-34.

Namkung, Y., \& Jang, S. (2008). Are highly satisfied restaurant customers really different? A quality perception perspective. International Journal of Contemporary Hospitality Management, 20(2), 142-155. https://doi.org/10.1108/09596110810852131

Nguyen, Q., Nisar, T. M., Knox, D., \& Prabhakar, G. P. (2018). Understanding customer satisfaction in the UK quick service restaurant industry: The influence of the tangible attributes of perceived service quality. British Food Journal, 120(6), 1207-1222. https://doi.org/10.1108/BFJ-08-2017-0449

Rahman, M., Kalam, A., Rahman, M., Abdullah, M. (2012). The influence of service quality and price on customer satisfaction: An empirical study on restaurant services in Khulna division. Research Journal of Finance and Accounting, 3(4), $8-15$.

Regenstein, J. M., Chaudry, M. M., \& Regenstein, C. E. (2003). The kosher and halal food laws. Comprehensive reviews in food science and food safety, 2(3), 111127. https://doi.org/10.1111/j.1541-4337.2003.tb00018.x

Rezai, G., Mohamed, Z., \& Shamsudin, M. N. (2012). Non-Muslim consumers' understanding of Halal principles in Malaysia. Journal of Islamic Marketing, 3(1), 35-46. https://doi.org/10.1108/17590831211206572

Rhee, H. T., Yang, S. B., \& Kim, K. (2016). Exploring the comparative salience of restaurant attributes: A conjoint analysis approach. International Journal of Information Management, 36(6),

1360-1370. https://doi.org/10.1016/j.ijinfomgt.2016.03.001

Saad, M., Toh, P. S., \& Mohamed Adil, M. A. (2013). Hygiene Practices of Food Handlers at Malaysian Government Institutions Training Centers. Procedia Social and Behavioral Sciences, 85, 118-127. https://doi.org/10.1016/j.sbspro.2013.08.344

Samori, Z., Salleh, N.Z., \&Khalid, M.M. (2016). Current trends on Halal tourism: Cases on selected Asian countries. Tourism Management Perspectives, 19, 131136. https://doi.org/10.1016/j.tmp.2015.12.011

Sham, R., Rasi, R. Z., Abdamia, N., Mohamed, S., \& Bibi, T. T. (2017, August). Halal logistics implementation in Malaysia: a practical view. In IOP Conference Series: Materials Science and Engineering (Vol. 226, No. 1, p. 012040). IOP Publishing. https://doi.org/10.1088/1757-899X/226/1/012040

Soraji, A. J., Awang, M. D., \& Mohd Yusoff, A. N. (2016). Malaysia Halal Trust: Between Reality and Challenges. Proceedings of ADVED 2016 2nd International Conference on Advances in Education and Social Sciences. 
Sumaedi, S., \& Yarmen, M. (2015). Measuring Perceived Service Quality of Fast Food Restaurant in Islamic Country: a Conceptual Framework. Procedia Food Science, 3, 119-131. https://doi.org/10.1016/j.profoo.2015.01.012

Tama, H.A., \& Voon, B.H. (2014). Components of Customer Emotional Experience with Halal Food Establishments. Procedia - Social and Behavioral Sciences, 121, 272-280. https://doi.org/10.1016/j.sbspro.2014.01.1128

World Tourism Organization. (2019). International Tourism Highlights 2019 Edition. UNWTO. https://doi.org/10.18111/9789284421152

World Tourism Organization. (2018). UNWTO Tourism Highlights 2018 Edition. UNWTO. https://doi.org/10.18111/9789284419876

Viverita, Kusumastuti, R. D., \& Rachmawati, R. (2017). Motives and Challenges of Small Businesses for Halal Certification: The Case of Indonesia. World Journal of Social Sciences, 7(1), 136-146.

Wan-Hassan, W.M., \& Awang, K.W. (2009). Halal Food in New Zealand Restaurants: An Exploratory Study. International Journal of Economics and Management, 3(2), 385-402.

Weiss, R., Feinstein, A. H., \& Dalbor, M. (2005). Customer satisfaction of theme restaurant attributes and their influence on return intent. Journal of Foodservice Business Research, 7(1), 23-41. https://doi.org/10.1300/J369v07n01_03

Yousaf, S., \& Xiucheng, F. (2018). Halal culinary and tourism marketing strategies on government websites: A preliminary analysis. Tourism Management, 68, 423-443. https://doi.org/10.1016/j.tourman.2018.04.006

Yusuf, A. H., Oyelakin, I. O., Abdul Shukor, S., \& Ahmad Bustamam, U. S. (2017). The Role of Halal Certification in Business Performance in Selangor: A Study on Kopitiam. Malaysian Management Journal, 21, 99-112.

Zailani, S., Iranmanesh, M., Aziz, A. A., \& Kanapathy, K. (2017). Halal Logistics Opportunities and Challenges. Journal of Islamic Marketing, 8(1), 127-139. https://doi.org/10.1108/JIMA-04-2015-0028

Živadinović, B. (2020). Tourist satisfaction with quality of service, food, atmosphere, and value for money in restaurants of major cities of the Western Balkans. The European Journal of Applied Economics, 17(2), 19-33. https://doi.org/10.5937/EJAE17-27360

Received: 11 January, 2021; Accepted: 30 January, 2021

Rad je primljen: 11.01.2021; Prihvaćen: 30.01.2021. 
